\title{
Creating Social Change in and Through Intercollegiate Sport: State of the Field, Challenges, and Future Directions
}

\author{
Jon Welty Peachey \\ University of Illinois
}

I write these concluding comments for the special issue on Creating Social Change in and through Intercollegiate Sport having just returned from attending the 3rd Annual Athletes and Social Change Forum at the Mohammad Ali Center in Louisville, Kentucky. Muhammad Ali served as a civil rights activist in his opposition to the Vietnam War, which cost him his heavyweight boxing title and four years of his career. In defense of his decision to boycott the war, Ali stated in 1966:

Why should they ask me to put on a uniform and go ten thousand miles from home and drop bombs and bullets on brown people in Vietnam while so-called Negro people in Louisville are treated like dogs and denied simple human rights? (Zirin, 2008, p. 147).

Propelled by the vision and legacy of Ali as an advocate for social change, practitioners, academics, athletes, and activists dialogued in Louisville about what it means for athletes to engage in social change, philanthropy, and work within the community. To begin the conference, Hudson Taylor, founder of Athlete Ally, which has a mission to end homophobia and transphobia in sport and now has chapters on 50 college campuses, challenged the attendees to better articulate the "why" and "what" of social change to mobilize people to action. "Social change does not happen without the support of the majority," said Taylor (Taylor, 2015a). Taylor also advocated that "we should focus on sport culture and the power of athletes to bring about social change." In fact, Taylor epitomizes how athletes can be activists and agitators for social change. As a student-athlete and former All-American wrestler at the University of Maryland, and former wrestling coach at Columbia University, Taylor observed first-hand the use of homophobic language and demeaning humor directed at LGBT student-athletes. He felt called to do something, and founded Athlete Ally as a means to educate athletic communities and combat discrimination against LGBT athletes.

The above remarks by Taylor, who is also an author of an article in this special issue, seem both prescient and prudent as we embark on exploring ways to create social change in and through intercollegiate sport. Without truly understanding the

Welty Peachey is with the Dept. of Recreation, Sport and Tourism, University of Illinois, Champaign IL. Address author correspondence to Jon Welty Peachey at jwpeach@illinois.edu. 
"why" and "what" of social change, we will be ineffective in our efforts. Without support of the majority, those in positions of power within college sport and influential decision makers, social change efforts will be inhibited if not altogether impossible.

The focus of this special issue is timely and critical as we consider the role sport can play in society (Eitzen \& Sage, 2009). As the call for papers indicates, the potential of sport-and those within it-to enact social change does not develop automatically, but instead requires individuals first to recognize a social injustice, and then consciously work toward creating social change. This special issue provides a forum for scholars and practitioners to contribute to this dialogue by stimulating thinking about how intercollegiate athletics can contribute to the social change agenda and by highlighting projects and research which have explored various facets of social change in and through intercollegiate sport. The articles in this special issue also provide insight into future directions and next steps for this agenda, which I will address further at the conclusion of this commentary. Theory building, conversation, and evaluation of sport for social change efforts throughout the sport industry are areas in much need of further development and refinement, as this is a nascent field (Coalter, 2013; Lyras \& Welty Peachey, 2011). As such, this special issue contributes significantly to the discourse.

I am delighted to provide concluding remarks and thoughts on the "state of the field" in sport and social change, situated within intercollegiate sport. I will first provide an overview of social change and sport for development and peace (SDP) and its historical context beginning with early athlete activists, before discussing specifically how scholars have thus far entered into the conversation regarding social change in and through intercollegiate sport. Tapping into the articles in this special issue and drawing from other work in social change in sport, I will conclude by articulating challenges, questions, next steps, and future directions for the field.

\section{Social Change and Sport for Development and Peace}

Sport for social change is the use of sport as a vehicle or platform for transforming the social structure of a social group or society (i.e., a change in the nature, social institutions, social behaviors, or social relations of a society) (Welty Peachey \& Cohen, 2012). The delineation of sport for social change is quite broad, and can constitute a program or initiative aimed at effecting change (i.e., SDP) or it can be instances where sport is used as a platform to advocate for a social cause or issue by athletes or other activists (e.g., Taylor's work with Athlete Ally described above, or the raised fists demonstrating Black Power at the 1968 Olympics by Tommie Smith and John Carlos). Within the area of sport for social change lies the SDP movement. SDP can be broadly defined as the use of sport to exert a positive influence on public health, the socialization of children, youth and adults, the social inclusion of the disadvantaged, the economic development of regions and states, and on fostering intercultural exchange and conflict resolution (Lyras \& Welty Peachey, 2011; Sugden, 2008). Organizations or groups involved in SDP often design and implement a sport-related program or initiative for the purpose of effecting social change (Welty Peachey \& Cohen, 2012). 
Most of the scholarly work and conversation to this point regarding sport and social change has taken place outside of the intercollegiate context, framed within the SDP movement. In this vein, numerous studies have begun to examine the efficacy and impact of sport-based interventions on achieving a variety of outcomes, such as building social capital among marginalized groups (Burnett, 2006; Skinner, Zakus, \& Cowell, 2008), facilitating social inclusion among the disenfranchised and marginalized (Sherry, 2010; Sherry \& Strybosch, 2012; Welty Peachey, Lyras, Borland, \& Cohen, 2013), and contributing to cross-cultural understanding and peace building efforts (Schulenkorf, Thomson, \& Schlenker, 2011; Sugden, 2008; Welty Peachey, Cunningham, Lyras, Cohen, \& Bruening, 2014). Another stream of literature has engaged with discourses and implications of neo-liberal and neocolonial agendas of SDP (Darnell, 2010; Darnell \& Hayhurst, 2011; Kidd, 2011; Levermore, 2008), while other scholars have begun to build theory around effective SDP program design (Coalter, 2013; Lyras \& Welty Peachey, 2011; Schulenkorf, 2012). What has not been investigated thoroughly, or even dialogued about in a scholarly sense until recently, is situating the social change agenda within intercollegiate sport.

\section{Historical Context}

The ancient Olympic Games provided the foundation for sport for social change, where the Games often created a truce between warring factions (Welty Peachey $\&$ Cohen, 2012). While we can debate the merit of corporate infringement upon the Olympic charter and the continued alignment of the modern Games with their original intent, it cannot be denied that specific moments in Olympic history have served as significant marking points for societal change, and that the Games have occasionally been used as a platform for athletes to advocate for social causes and social change. One of the more memorable instances was when Jesse Owens won four gold medals in the 1936 Berlin Olympics in the face of Nazi white supremacy propaganda, which served as an inspiration for minority individuals around the world. Sprinters Tommie Smith and John Carlos also used the Olympic stage in 1968 to make a political statement about Black Power by raising their fists enveloped in black gloves during the medal ceremony. More recently, Australian Cathy Freeman, during the 2000 Sydney Games, served as an advocate for Aboriginals who have historically experienced racism in Australia, by receiving the honor of lighting the Olympic flame.

Beyond the Olympics and other than Ali's leverage of his boxing fame to protest the Vietnam War, other historic events in sport and individual athletes have also advanced and agitated for the social change agenda. One of the most important instances of social change in sport occurred in 1947 when Jackie Robinson broke the color barrier in Major League Baseball (MLB) with the Brooklyn Dodgers, an event that transcended baseball and had a direct impact on racial segregation in the U.S. In 1973, tennis great Billie Jean King engaged in the infamous "Battle of the Sexes" match with Bobby Riggs in which she triumphed. King subsequently leveraged this notoriety to become one of the most prominent activists for women's rights, beginning the Women's Sport Foundation in 1974. The 1995 Rugby World Cup in South Africa, which took place following the end of apartheid as Nelson Mandela became the first black president of South Africa after serving 27 years 
in prison, has been heralded as a significant step in unification of white and black South Africans. The symbolism of Mandela presenting the championship trophy to the captain of the Springboks (South Africa's national team), a famous white athlete in the country, was not lost on the world.

Professional sport teams and athletes have also become involved in using their platform to advocate for issues or causes. For example, in 2010 the National Basketball Association's (NBA) Phoenix Suns chose to wear jerseys which said "Los Suns" on them to protest new immigration laws that were passed in Arizona. In addition, in August 2014, Michael Brown was shot and killed by police in Ferguson, Missouri. The resulting public outcry from this perceived unjustified shooting led to the "Hands Up, Don't Shoot" campaign which spread throughout the U.S. after the grand jury's decision not to indict the police officer involved, citing evidence he was acting in self-defense. Subsequently, on November 30, 2014, several players from the National Football League's (NFL) St. Louis Rams entered the field before a game with their hands up, in support of the campaign. The St. Louis Police Officers Association requested the NFL punish the players, but the NFL refused, saying that the gesture was political and the NFL does not punish players for their political gestures.

Within the college sport landscape, student-athletes on the Northwestern University football team energized conversation throughout college sport by proposing to form a union for student-athletes, arguing that athletes are employees of the university. The regional director of the National Labor Relations Board (NLRB) made a ruling in 2014 that scholarship football players at Northwestern are employees of the university and may be represented by a union. However, the university has appealed to the full NLRB to overturn the ruling. And finally, as I pen this commentary, the National Collegiate Athletic Association's (NCAA) Men's Basketball Final Four has just taken place in Indianapolis, Indiana, on the cusp of the Governor of Indiana's (Mike Pence) signing a law that could potentially make it legal to discriminate against LGBT individuals. On the same weekend as the Final Four, athletes and community leaders gathered in Indianapolis to raise public awareness about the new law, and emphasize a call to action for sport to play a significant role in the enhancement of LGBT rights (see Cunningham's article in this special issue for an example of how athletic departments can potentially do just this). This campaign, called \#FinalFourFairness and organized by Athlete Ally, mobilized thousands of sports fans and several professional athletes in support.

As this brief review highlights, sport has been tapped as a social change mechanism by scholars, athletes, and activists throughout the past century, both through designing and implementing sport-based interventions to achieve specified outcomes (e.g., SDP), and as a platform to advocate for social change and various causes. However, much more dialogue, theory, and empirical research is still needed to fully explore sport's capacity (or perhaps noncapacity) to enact social change throughout and through all segments of the sport industry.

\section{Sport for Social Change and Intercollegiate Sport}

Regrettably, to this point, thinking and scholarship addressing social change in and through college sport have been minimal, although there have indeed been good efforts in this regard. The Drake Group, founded in 1999, is a think tank of 
academics, practitioners, and policy makers that has at its core a vision to "create an atmosphere on college campuses that encourages personal and intellectual growth for all students, and demands excellence and academic integrity from faculty charged with teaching" (Group, 2015, 4th par.). Since its founding, the group has been working as an advocate for policy change in college sport to end academic corruption. In terms of scholarship, one important, recent work by Jennifer Bruening and colleagues (2015) examined the capacity of a service-learning program for college student-athletes to effect social change, particularly through the strategic design and management of the program. These scholars investigated social capital development among alumni of a sport-based inner city service learning engagement, and found that the intentional design, management and structure of the program, in line with Sport for Development Theory (Lyras \& Welty Peachey, 2011), aided in this development over time. This same group of scholars has a contribution in this special issue (Fuller et al., 2015) as a follow-up to the above referenced work, finding importantly that alumni indicated the service learning experience was critical to helping them recognize social injustices in the world, and that it fostered civic engagement, stimulating future intentions and current involvement in social justice related initiatives. Together, these works are showing that service learning experiences and environments are an important vehicle for creating social change through intercollegiate sport. Future research is needed to further explore the many possibilities inherent in the merging of service learning and social change.

A recent special issue in this journal centered on Ethical Leadership in Intercollegiate Sport highlighted the need to change our leadership paradigm in intercollegiate athletics to best serve the needs of student-athletes and to mobilize action for social change. Contributors called for a new ethos of leadership focused on ethical leadership to remove gray areas and help to realize the true potential of sport to shape lives of young men and women, and to help address societal issues (Roby, 2014; Sagas \& Wigley, 2014). Staurowsky (2014) also pointed out, in her commentary, that we have a core ethical obligation to ensure academic freedom of college athletes, particularly those in big-time revenue generating sports. She highlighted the All Players United Campaign, in which less than two dozen college student-athletes from the University of Georgia, Georgia Tech, and Northwestern University wore wristbands with the letters "APU" (All Players United) on them in the fall of 2013 in support of other collegiate football players who had filed two lawsuits challenging the NCAA on failure to share revenues from use of their names and likenesses, and challenging the NCAA's failure to protect athletes by withholding information on concussions (Staurowsky, 2014). In the end, DeSensi (2014) echoed Burton and Welty Peachey's (2013) earlier contention that the servant leadership paradigm (Greenleaf, 1977), which has at its core a focus on building relationships and development of followers, could be a leadership style necessary in intercollegiate sport to rectify inequalities and change systematic patterns and practices. Thus, in many respects, servant leadership could be a leadership paradigm vital to enact social change in and through the college sport environment.

In this special issue, contributors build upon the previous work highlighted above and move the study of social change in collegiate sport in intriguing new directions. In addition to Fuller et al. (2015) and Cunningham (2015) mentioned above, Taylor provides a personal narrative of his experiences as a college wrestler in a homophobic environment discriminating, more covertly than overtly, against 
LBGT individuals, and how this motivated and activated him to work for social change by founding Athlete Ally (Taylor, 2015b). Importantly, Taylor calls for leveraging activist activities for LGBT issues to address other aspects of discrimination in sport, such as racism, classism, and sexism. More stories such as Taylor's need to be shared, both within and outside of the walls of academia, to stimulate others to work for change. Cunningham compliments this telling narrative by advocating that intercollegiate athletic departments which are inclusive of LGBT individuals can act as social change agents by deinstitutionalizing dominant logics of action focused on heterosexism and exclusivity, and then reinstitutionalizing new practices and structures inclusive of LGBT diversity. These individuals and departments can serve as a social change stimulus for other athletic departments around LGBT issues, but more broadly, I suggest could also serve as actors to desinstitutionalize other discriminatory practices in college sport (Welty Peachey \& Bruening, 2011). Finally in this special issue, along a different yet highly necessary and interesting agenda, Martin, Ross, and Irwin (2015) show that a community-based social marketing process was effective in positively changing the recycling behavior of tailgaters. This marketing campaign is even more effective when students and student-athletes are involved.

All of the work in this special issue points toward the vital role various stakeholders, whether allies, student-athletes, students, or entire athletic departments, play in mobilizing social change. The scholars in this issue have made important strides in furthering the conversation around social change in intercollegiate sport, and have collectively provided numerous suggestions to engage with and stimulate further scholarship in this area. Below, building upon the excellent work begun here, I reflect upon additional future directions and challenges for scholarship and conversation around creating social change in and through college sport.

\section{Future Directions, Conversations, and Challenges}

One future direction for scholarship, and a considerable challenge, when thinking about social change in and through college sport revolves around theory building. Scholars have called for further work in theory development within the field of sport for social change and SDP (Lyras \& Welty Peachey, 2011), however, to date, theorizing about sport for social change in the intercollegiate context has been minimal. While work has begun to theorize about the design and leverage of SDP (Coalter, 2013; Lyras \& Welty Peachey, 2011; Schulenkorf, 2012), this conversation has not yet entered the intercollegiate sport arena. Might there be unique stakeholder influences, forces, cultures, and constraints in intercollegiate athletics that either facilitate or inhibit social change initiatives and activism, as alluded to by Melton (2015) in her introduction to this special issue? Similarly, more work is needed to ascertain the mechanisms through which social change can be enacted in and through college sport, and the features/components of programs and initiatives which facilitate specified outcomes (Lyras \& Welty Peachey, 2011). It could be that the features and components of social change programs in college sport may differ from effective social change and SDP program design features in other settings. Essentially, scholars are still wrestling with the question of whether 
there is a universal theory that can be applied to sport for social change work and SDP, or whether contextual influences are so great that a universal theory is not possible, and theorizing should focus more on contextual nuancing and sensitivity (Coalter, 2013, Lyras \& Welty Peachey, 2011). Thus, this is an avenue in much need of continued dialogue and scholarship.

Another interesting line of inquiry would be to explore the motivation of athletes and athletic departments for engaging in social change work and activism. What are the drivers of their involvement, and what sustains their work for social change over time? Are these motivations and retention factors different from motivations of individuals and organizations involved in sport for social change and SDP in other segments of the sport industry? An understanding of these motivations and why individuals and athletic departments continue with their advocacy and initiatives over time could be tapped to attract more athletes and athletic administrators to engage with social change efforts, and to keep them involved over time. In addition to motivations, a challenge and opportunity for future research lies in ascertaining and exploring the potential long-term outcomes of social change initiatives and activism in college sport. Admittedly, most of the impact studies and research conducted in sport for social change and SDP have not been longitudinal in nature, as many of the programs are short lived themselves and it is often difficult to track down program participants years later to gather data (Coalter, 2013). However, there are initial efforts in this regard, and even in this special issue, Fuller and colleagues (2015) examine the long-term outcomes of an inner city service learning experience on college student participants. Thus, scholars should endeavor to conduct longitudinal research whenever possible, as identifying potential long-term outcomes of social change initiatives in college sport will give both credibility and justification to these efforts.

As Melton (2015) referenced in her introduction to this special issue, and as other scholars have highlighted (Ponic, Reid, \& Frisby, 2010; Schinke, McGannon, Watson, \& Busanich, 2013), partnerships and collaborations are vital to the success and sustainability of social change efforts. Within the intercollegiate sport landscape, what might these partnerships and collaborations look like? How are they formed, and how sustained? What are the outcomes of these partnerships? What factors and forces inhibit effective partnership formation and sustainability? While Walker and Melton's (2015) interview with Kate Fagan provides some insight, scholars need to address these and other intriguing questions related to industry partnerships. Leadership in the sport for social change context also needs further exploration and theorizing. Perhaps, as I and other scholars have discussed, servant leadership (Greenleaf, 1977) could be a new leadership paradigm particularly relevant to social change efforts due to its inherent focus on development of and care for followers. Burton and Welty Peachey (2013) and DeSensi (2014) have called for further exploration of servant leadership within intercollegiate sport, and I echo this charge. Further work should examine the relevance and effectiveness of servant leadership in guiding and sustaining social change efforts, but additionally, scholarship should more broadly examine the nature of leadership in sport for social change. There may be other leadership styles (e.g., authentic, transformational) which are highly effective in a sport for social change environment.

Along a related path, exploring social change through the lens of social entrepreneurship would have merit (see Cohen \& Welty Peachey, 2014). Social 
entrepreneurs are innovative and engage in social value creating activity (Austin, Stevenson, \& Wei-Skillern, 2006). As Cohen and Welty Peachey (2014) indicate, "social entrepreneurs may have a significant ability to provide positive social returns to society" (p. 114). While work using social entrepreneurship theory has been applied in the context of SDP with a champion in a homeless initiative in the U.S. (see Cohen \& Welty Peachey, 2014), little if any work has employed this lens to examine how activists and champions for social change in intercollegiate sport emerge, grow, and find success. This would also be a fruitful line of inquiry.

\section{Concluding Thoughts}

In this commentary, I have endeavored to shape the context and scholarship related to creating social change in and through intercollegiate sport. I commend the scholars in this special issue for moving this conversation forward, providing, I hope, a stimulus for other scholars to engage with the social change agenda in the intercollegiate sport context. I believe this special issue and previous scholarship and conceptual thinking in this field demonstrates that progress has been made, but there remain many questions in need of scholarly inquiry and conversation. To conclude my comments, I offer for consideration a quote by scholar Grant Jarvie on the potential of sport and social change:

Historically, the potential of sport lies not with the values promoted by global sport or particular forms of capitalism for these are invariably unjust and uneven. The possibilities that exist within sport are those that can help with radically different views of the world perhaps based upon opportunities to foster trust, obligations, redistribution, and respect for sport in a more socially oriented humane world (Jarvie, 2007, p.422).

Let us all consider how we can contribute to a radically different conversation and view of intercollegiate sport, and how it and its agents can be activists and agitators for social change.

\section{References}

Austin, J., Stevenson, H., \& Wei-Skillern, J. (2006). Social and commercial entrepreneurship: Same, different, or both? Entrepreneurship Theory and Practice, 30(1), 1-22. doi:10.1111/j.1540-6520.2006.00107.x

Bruening, J., Welty Peachey, J., Evanovich, J., Noble, C., Fuller, R., Percy, V., \& Silverstein, L. (2015). Managing sport for social change: The effects of intentional design and structure in a sport-based service learning initiative. Sport Management Review, 18, 69-85. doi:10.1016/j.smr.2014.07.002

Burnett, C. (2006). Building social capital through an active community club. International Review for the Sociology of Sport, 41(3-4), 283-294. doi:10.1177/1012690207078381

Burton, L., \& Welty Peachey, J. (2013). The call for servant leadership in intercollegiate athletics. Quest, 65, 354-371. doi:10.1080/00336297.2013.791870

Coalter, F. (2013). 'There is loads of relationships here': Developing a program theory for sport-for-change programs. International Review for the Sociology of Sport, 48, 594-612. doi:10.1177/1012690212446143 
Cohen, A., \& Welty Peachey, J. (2015). The making of a social entrepreneur: From participant to cause champion within a sport-for-development context. Sport Management Review, 18, 111-125. doi:10.1016/j.smr.2014.04.002

Cunningham, G. (2015). LGBT inclusive athletic departments as agents of social change. Journal of Intercollegiate Sport, 8, 43-56.

Darnell, S. (2010). Power, politics and "sport for development and peace": Investigating the utility of sport for international development. Sociology of Sport Journal, 27(1), 54-75.

Darnell, S.C., \& Hayhurst, L.M. (2011). Sport for decolonization: Exploring a new praxis of sport for development. Progress in Development Studies, 11(3), 183-196. doi:10.1177/146499341001100301

DeSensi, J.T. (2014). Sport: An ethos based on values and servant leadership. Journal of Intercollegiate Sport, 7, 58-63. doi:10.1123/jis.2014-0097

Greenleaf, R.K. (1977). Servant leadership: A journey into the nature of legitimate power and greatness. New York: Paulist Press.

Group, T.D. (2015). Academic integrity in college sport. The Drake Group. Retrieved from http://thedrakegroup.org/about/histroy

Eitzen, D.S., \& Sage, G.H. (2009). Sociology of North American Sport. Boulder, CO: Paradigm Publishers.

Fuller, R., Evanovich, J., Bruening, J., Welty Peachey, J., Coble, C., Percy, V., Maladouangdock, J., \& Corral, M. (2015). The impact of a sport-based service learning course on participants' attitudes, intentions and actions towards social change. Journal of Intercollegiate Sport, 8, 14-36.

Jarvie, G. (2007). Sport, social change and the public intellectual. International Review for the Sociology of Sport, 42(4), 411-424. doi:10.1177/1012690208089834

Kidd, B. (2011). Cautions, questions, and opportunities in sport for development and peace. Third World Quarterly, 32, 603-609. doi:10.1080/01436597.2011. 573948

Levermore, R. (2008). Sport a new engine of development? Progress in Development Studies, 8(2), 183-190. doi:10.1177/146499340700800204

Lyras, A., \& Welty Peachey, J. (2011). Integrating sport for development theory and praxis. Sport Management Review, 14, 311-326. doi:10.1016/j.smr.2011.05.006

Martin, N., Ross, S., \& Irwin, R. (2015). Utilizing community-based social marketing in a recycling intervention with tailgaters. Journal of Intercollegiate Sport, 8, 57-81.

Melton, N. (2015). Creating social change in and through intercollegiate sport. Journal of Intercollegiate Sport, 8, 1-13.

Ponic, P., Reid, C., \& Frisby, W. (2010). Cultivating the power of partnerships in feminist participatory action research in women's health. Nursing Inquiry, 17, 324-335. PubMed doi:10.1111/j.1440-1800.2010.00506.x

Roby, P. (2014). Ethical leadership in college athletics. Journal of Intercollegiate Sport, 7, 35-39. doi:10.1123/jis.2014-0086

Sagas, M., \& Wigley, B.J. (2014). Gray area ethical leadership in the NCAA: The ethics of doing the wrong things right. Journal of Intercollegiate Sport, 7, 40-57. doi:10.1123/jis.2014-0084

Schinke, R.J., McGannon, K.R., Watson, J., \& Busanich, R. (2013). Moving toward trust and partnership: An example of sport-related community-based participatory action research with Aboriginal people and mainstream academics. Journal of Aggression, Conflict and Peace Research, 5(4), 201-210. doi:10.1108/ JACPR-11-2012-0012

Schulenkorf, N. (2012). Sustainable community development through sport and events: A conceptual framework for Sport-for-Development projects. Sport Management Review, 15, 1-12. doi:10.1016/j.smr.2011.06.001 
Schulenkorf, N., Thomson, A., \& Schlenker, K. (2011). Intercommunity sport events: Vehicles and catalysts for social capital in divided societies. Event Management, 15(2), 105-119. doi:10.3727/152599511X13082349958316

Sherry, E. (2010). (Re)engaging marginalized groups through sport: The Homeless World Cup. International Review for the Sociology of Sport, 45, 59-71. doi:10.1177/1012690209356988

Sherry, E., \& Strybosch, V. (2012). A kick in the right direction: Longitudinal outcomes of the Australian Street Soccer Program. Soccer \& Society, 13(4), 495-509. doi:10.1080/14660970.2012.677225

Skinner, J., Zakus, D.H., \& Cowell, J. (2008). Development through sport: Building social capital in disadvantaged communities. Sport Management Review, 11, 253-275. doi:10.1016/S1441-3523(08)70112-8

Staurowsky, E. (2014). College athletes' rights in the age of the super conference: The case of the All Players United Campaign. Journal of Intercollegiate Sport, 7 , 11-34. doi:10.1123/jis.2013-0052

Sugden, J. (2008). Anyone for Football for Peace? The challenges of using sport in the service of co-existence in Israel. Soccer \& Society, 9(3), 405-415. doi:10.1080/14660970802009023

Taylor, H. (2015a, April). Athletes for equality. Paper presented at the Athletes \& Social Change Forum, Louisville, KY.

Taylor, H. (2015b). Activating change through allyship. Journal of Intercollegiate Sport, 8, 37-46.

Walker, N. A., \& Melton, E. N. (2015). Creating opportunities for social change in women's sport through academic and industry collaboration: An interview with Kate Fagan. Journal of Intercollegiate Sport, 8, 82-95.

Welty Peachey, J., \& Bruening, J. (2011). An examination of environmental forces driving change and stakeholder responses in a Football Championship Subdivision intercollegiate athletic department. Sport Management Review, 14(2), 202-219. doi:10.1016/j.smr.2010.09.002

Welty Peachey, J., \& Cohen, A. (2012). Sport for social change and development. In G.B. Cunningham \& J.N. Singer (Eds.), Sociology of sport and physical activity (2nd ed.). College Station, TX: Center for Sport Management Research and Education.

Welty Peachey, J., Cunningham, G., Lyras, A., Cohen, A., \& Bruening, J. (2014). The influence of a sport for development event on prejudice and change agent self-efficacy. Journal of Sport Management; Advance online publication.

Welty Peachey, J., Lyras, A., Borland, J., \& Cohen, A. (2013). Sport for social change: Investigating the impact of the Street Soccer USA Cup. ICHPER-SD Journal of Research, 8(1), 3-11.

Zirin, D. (2008). A people's history of sports in the United States. New York: The New Press. 